ARTIGO

Recebido em: 04/05/2016

Aceito em: $12 / 08 / 2016$

\title{
Scientific collaboration between Brazil and Spain: journals and citations
}

\section{Colaboração científica entre Brasil e Espanha: periódicos e citações}

Samile Andrea de Souza VANZ

Professora do Departamento de Ciências da Informação - UFRGS - samilevanz@terra.com.br

Daniela DE FILIPPO

Professora do Departamento de Biblioteconomia e Documentação, Universidad Carlos III de Madrid - dfilippo@bib.uc3m.es

\section{Sônia Elisa CAREGNATO}

Professora do Departamento de Ciências da Informação - UFRGS -sonia.caregnato@ufrgs.br

\section{Carlos GARCÍA-ZORITA}

Professor do Departamento de Biblioteconomia e Documentação, Universidad Carlos III de Madrid - czorita@bib.uc3m.es

Ana Maria Mielniczuk de MOURA

Professora do Departamento de Ciências da Informação - UFRGS - ana.moura@ufrgs.br

\section{Maria Luisa LASCURAIN SANCHEZ}

Professora do Departamento de Biblioteconomia e Documentação, Universidad Carlos III de Madrid - mlascura@bib.uc3m.es

\section{Elias SANZ-CASADO}

Professor do Departamento de Biblioteconomia e Documentação, Universidad Carlos III de Madrid - elias@bib.uc3m.es

\begin{abstract}
Collaboration in science has been studied from different perspectives. At a country level, it is important to determine whether international collaboration improves the quality and visibility of a nation's output of papers. This study is part of a research work that seeks to map the characteristics of the scientific production of Brazil and Spain and the documents produced in collaboration between them. The objective of the analysis presented here was to establish the importance of collaboration for each country and of the vehicles used for publishing, by observing indicators for the first quartile and citations. The corpus of the research is comprised of publication records that contain at least one Brazilian and Spanish address in the author address field, from 2006 to 2012, in the Web of Science databases. Findings suggest that for Brazil, international scientific collaboration with Spain raises the number of articles published in Q1 journals. Therefore, the country should continue promoting this type of collaboration. For Spain, collaboration with Brazil is not reflected in impact. The increased number of agreements and the incentives given to projects in collaboration between the two countries could expand the quality and visibility of their output.
\end{abstract}

Keywords: Bibliometrics. Scientometrics. Scientific Collaboration. Scientific Journal. Brazil.

v. 21, n. 47,2016 p. $41-50$

ISSN 1518-2924 Spain.

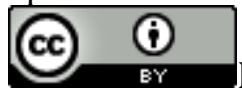

Esta obra está licenciada sob uma Licença Creative Commons. 


\section{Resumo}

A colaboração científica tem sido estudada a partir de diferentes perspectivas. Determinar se a colaboração internacional melhora a qualidade e visibilidade dos artigos publicados por um país é um dos aspectos mais importantes. Este estudo é parte de um projeto de pesquisa que visa mapear as características da produção científica do Brasil e da Espanha e os documentos produzidos em colaboração entre esses dois países. 0 objetivo da análise aqui apresentada foi estabelecer a importância da colaboração para cada país e os veículos utilizados para publicação, observando indicadores de quartil e citações. O corpus da pesquisa é composto por publicações que contêm pelo menos um endereço brasileiro e espanhol no campo de endereço autor, de 2006 a 2012, na Web of Science. Os resultados mostram que para o Brasil, a colaboração científica internacional com a Espanha aumenta o número de artigos publicados em revistas Q1. Portanto, o país deve continuar a promover este tipo de colaboração. Para a Espanha, a colaboração com o Brasil não reflete no impacto das publicações. 0 aumento do número de convênios e os incentivos aos projetos em colaboração entre os dois países poderiam expandir a qualidade e visibilidade da sua produção.

Palavras-chave: Bibliometria. Cienciometria. Colaboração Científica. Periódico científico. Brasil. Espanha.

\section{INTRODUCTION}

The international scientific collaboration has become one of the main characteristics of the current scientific activity, bringing out the importance of interdisciplinarity and knowledge exchange among the scientific community from different countries. "By being international in outlook, a nation can enhance the quality of its domestic science, absorb expertise and ideas from partners and competitors around the world, share risk and pool resource." (Royal Society, 2011, p. 37).

The scientific collaboration can be motivated by different factors: economic ones, due to the high cost of science and the possibility of sharing resources and investments; cognitive, related to the acquisition of new knowledge; and social, related to the network of professional and personal relationships of the researcher, as well as emotional and ideological affinity (Luukkonen et al., 1992). Due to its importance, international collaboration in science has been explored in different studies.

According to Frame and Carpenter (1979), openness to international collaboration is closely related to language, geographical proximity, country scientific excellence, country facilities offered to develop research and also political reasons. Another cause that promotes collaboration is the increased visibility acquired by publications that are internationally coauthored. Due to Lewison (1991), and Narin and Whitlow (1991) this kind of publication is more frequently cited than others. Bridgstock (1991), in turn, shows that there is a correlation between the number of authors and number of citations received. In the same way, Van Raan (1998) and Gomez et al. (1999) point out that international collaboration promotes visibility due to its larger audience and its publication in journals that have greater impact.

In the opinion of Zitt et al. (2000), international collaboration is, first of all, determined by the size of the country. Secondly, it is influenced by the closeness between countries, both physical-geographical and in an "immaterial way", i.e., through a cultural affinity in a broad sense (historical, linguistic) or due to economic factors. Regardless of the motivation, articles written in international collaboration receive more citations, which grow in number more rapidly than citations for articles done in collaboration at the domestic level (Wagner \& Leydesdorff, 2005). 
However, participation in large networks cannot always be considered as an indicator of the degree of a country's development, since it may be collaborating in an "assymetrical" manner, with more highly developed groups, in order to enhance its capabilities (Kim et al., 2006). For this reason, measuring the contribution of a country in international collaboration enables each one's real contribution to be more accurately assessed. Therefore, it is necessary to know the main output characteristics of each country involved, as well as determine its output and collaboration standards and analyze the impact that the collaboration produces in its counterpart in each scientific field. In so doing, it will be possible to truly know the strengths of the cooperation.

The work presented here is part of a bilateral project financed by Ministerio de Educación, Cultura y Deporte from Spain and Coordenação de Aperfeiçoamento de Pessoal de Nível Superior (CAPES) from Brazil. The research aims to identify scientific collaboration by means of papers written by authors from both countries. Accordingly, this paper seeks to map the output characteristics of Brazil and Spain and the documents produced in collaboration, as well as to present the findings of the second stage of the research, in reference to journals chosen for publication by Brazilian and Spanish authors separately and in collaboration. The objective of the analysis was to characterize the vehicles used for publishing, by observing indicators for quality, such as the first quartile; and visibility, such as citations.

\section{METODOLOGY}

The main data source was Web of Science (WoS). The corpus of the research is comprised of all kind of publications that contain at least one Brazilian and Spanish address in the author address field, from 2006 to 2012, in the databases Science Citation Index, Social Science Citation Index and Arts \& Humanities Citation Index, in accordance with the method used by Kim et al. (2006). Information was also sought in the Journal Citation Report 2013 to supplement the research. The data was organized in a SQL database and the analyses were performed with " $R$ " software. The tables and figures were created with Microsoft Office Excel, Version 2007.

For subject categorization, the Web of Science journal classification system was applied. Because of the extensive number of "WoS categories" (around 250), they were aggregate into 12 major categories according to the classification proposed by Glänzel e Schubert (2003).

\section{RESULTS AND DISCUSSION}

From 2006 to 2012, a total number of 373,313 documents were published in Spain, 246,939 in Brazil, and 6,117 documents were published in collaboration between both countries, of which 2,819 were in bilateral collaboration, that is, documents published only by Brazil and Spain, and 3,298 in multilateral collaboration, that is, documents published by Brazil, Spain and other countries.

Scientific collaboration between Brazil and Spain is weak, in view of the fact that the number of documents published in bilateral and multilateral co-authorship is very small: 2,819 and 3,298 respectively (Figure 1). Even though these numbers are low, since they represent $2.5 \%$ of Brazil's scientific production and $1.7 \%$ of Spain's, they have been constantly growing in recent years - more than the individual growth of each country (Moura et al., 2015). Overall, Brazilian numbers have plateaued for a few years in terms of international collaboration (Vanz \& Stumpf, 2012; Leta et. al, 2013) despite different government incentives to internationalize science, such as the program "Ciencia sem Fronteiras". In this study, $25.54 \%$ of Brazilian scientific output is published in international 
collaboration. In Spain, this figure rises to $39.2 \%$, which may be a reflection of Spain's longer history in collaborative research and internationalization, which has increased in recent years (De Filippo et al, 2010; 2014). The results confirm that Brazil and Spain are at different levels regarding to international collaboration. According to Royal Society (2011), less than $26 \%$ of scientific papers are the product of one institution alone and over $35 \%$ of articles published in international journals are internationally collaborative.

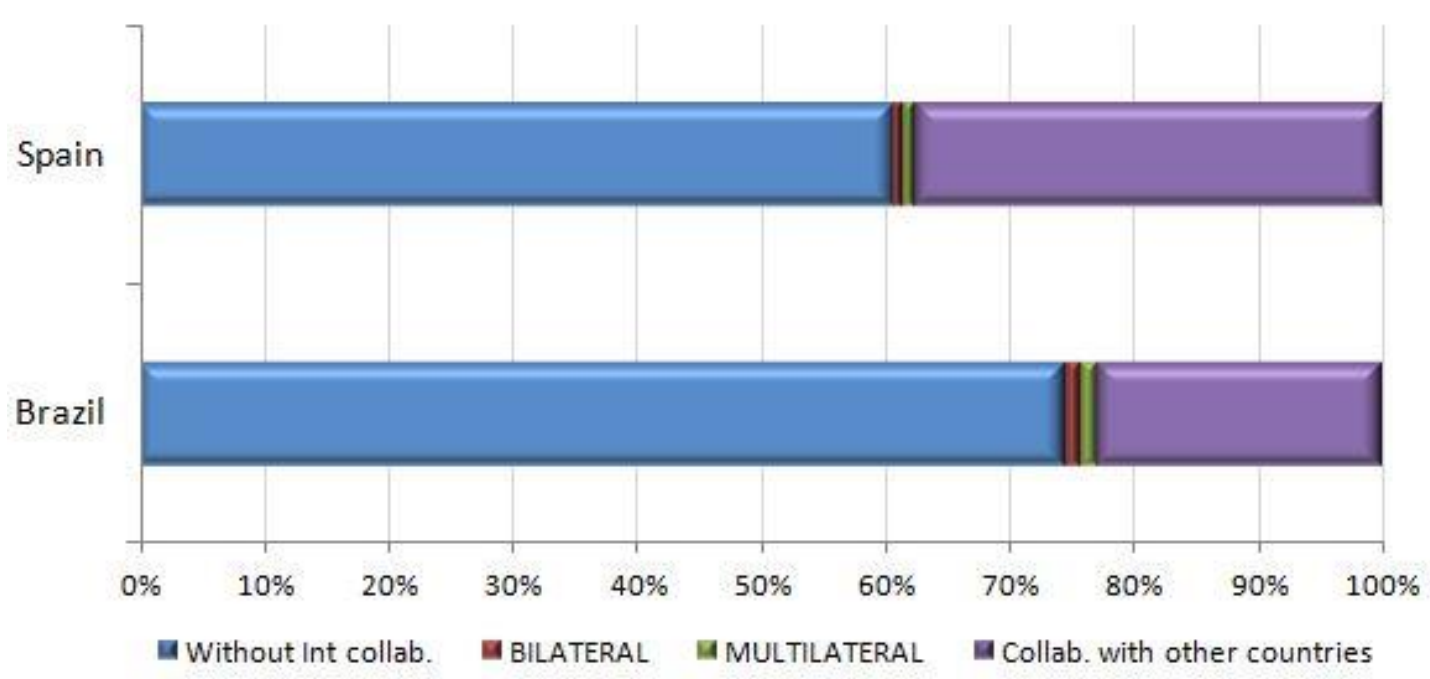

Figure 1: Proportion of documents indexed on Web of Science databases from Brazil and Spain according to type of international collaboration, 2006-2012.

Source: survey data.

To analyze national and international collaboration in both countries a chisquare test was performed. One of the main outcomes is the comparison between expected and observed results (according to data distribution). The results show that the number of Brazilian papers written in international collaboration is less than expected, whereas in Spain this number is higher than expected, as seen in Table 1:

Table 1: Number of documents indexed on Web of Science databases from Brazil and Spain according to type of international collaboration, 2006-2012.

\begin{tabular}{|c|c|c|c|c|c|c|c|c|}
\hline & \multirow{2}{*}{\multicolumn{2}{|c|}{$\begin{array}{l}\text { Docs WITHOUT } \\
\text { international } \\
\text { collaboration }\end{array}$}} & \multicolumn{6}{|c|}{ Docs WITH international collaboration } \\
\hline & & & \multicolumn{2}{|c|}{$\begin{array}{c}\text { Bilateral } \\
\text { collaboration }\end{array}$} & \multicolumn{2}{|c|}{$\begin{array}{l}\text { Multilateral } \\
\text { collaboration }\end{array}$} & \multicolumn{2}{|c|}{$\begin{array}{c}\text { Collaboration with } \\
\text { other countries }\end{array}$} \\
\hline & $\begin{array}{l}\text { Number } \\
\text { found }\end{array}$ & $\begin{array}{l}\text { Number } \\
\text { expected }\end{array}$ & $\begin{array}{l}\text { Number } \\
\text { found }\end{array}$ & $\begin{array}{l}\text { Number } \\
\text { expected }\end{array}$ & $\begin{array}{l}\text { Number } \\
\text { found }\end{array}$ & $\begin{array}{l}\text { Number } \\
\text { expected }\end{array}$ & $\begin{array}{l}\text { Number } \\
\text { Found }\end{array}$ & $\begin{array}{l}\text { Number } \\
\text { expected }\end{array}$ \\
\hline Brazil & 183,871 & 163,575 & 2,819 & 2,245 & 3,298 & 2,626 & 56,951 & 78,493 \\
\hline Spain & 226,990 & 247,286 & 2,819 & 3,393 & 3,298 & 3,970 & 140,206 & 118,663 \\
\hline
\end{tabular}

Source: survey data. Note: $\mathrm{P}=<0.005$ degree of association (contingency coefficient) $=0.15$

The results show that the number of documents without international collaboration was higher than expected in the Brazilian case, indicating that it is necessary to expand publication in international collaboration. Spain presents an opposite situation: the country has a smaller number of documents without international collaboration than expected. This analysis reveals different publication profiles for each country: Brazil has yet to improve international collaboration, whereas Spain has achieved a higher position. The collaboration with other countries column in Table 1 indicates that Spain has more documents than expected in this category, whereas Brazil has less than expected. 
Spain accounts for $5.9 \%$ of the documents published in international collaboration with Brazil, occupying the 6th position among the countries partners (Fundação..., 2011). When the scientific output is relativized in relation to Brazilian output, Spain stands out as one of the Brazilian strongest partners (Vanz \& Stumpf, 2012).

The existence of oficial agreements and support programs to do research in international collaboration are important. Brazil has technical agreements with Spain since 1992, a very recent date, considering that the agreements with the United States were signed as far back as the 1950's (Fundação..., 2011). The contemporaneity of agreements signed by Spain and Brazilian Ministério de Relações Exteriores, Capes and CNPq reflect positively in the results observed in this study.

More recently, through DGU/CAPES, a program signed by CAPES and Spanish Direccion General de Universidads (DGU), the Brazilian agency has intensified support for joint research projects aiming at scientific exchange between Brazilian and Spanish universities, in addition to training human resources (Coordenação..., 2015).

São Paulo state has its especific agency namely FAPESP, who has many agreements to promote scientific and technical collaboration between Spanish researchers and that ones from São Paulo, through supporting research projects with Universidad de Girona, Universidad Complutense de Madrid and Universidad de Salamanca. In addition to universities, FAPESP has signed with Agencia Estatal Consejo Superior de Investigaciones Cientificas (CSIC), from Spain, a memorandum of understanding in order to support the joint preparation of research proposals calls, support and promote the researchers and students exchange and to support technical information and research results sharing (Fundação... 2015).

Brazilian government agencies named Financiadora de Estudos e Projetos (Finep/MCTI) and the Centro para o Desenvolvimento Tecnológico Industrial (CDTI), have technological agreements to promote innovation in business, technology centers and universities from Brazil and Spain, and also, exchange knowledge and best practices between the institutions.

In order to deepen analysis and understand the publishing profile of each country, journals used for publication were identified and related to country publisher and Quartil. The results are shown next.

With respect to journals, the results also show that Brazil and Spain have different publication profiles. The analysis of the quartile of the journals indicates that $30.98 \%$ of Brazilian scientific output is published in Q1 journals, whereas the rate in Spain is higher (49.05\%). The discrepancy in percentages between the two countries is also reflected in the analysis of bilateral publications, with $41.97 \%$ in Q1 journals (Table 2). These results show that, for Brazil, bilateral collaboration with Spain improves impact, while collaboration with Brazil does not have such beneficial results for Spain. 
Table 2: Documents from Brazil, Spain and in bilateral collaboration indexed on Web of Science databases according to type of journals, 2006-2012.

\begin{tabular}{lrcc}
\hline Documents & Brazil & Spain & Bilateral collaboration \\
\hline No. of documents & 246,939 & 373,313 & 2,819 \\
No. of docs in Q1 journals & 76,513 & 183,128 & 1,183 \\
\% of docs in Q1 journals & 30.98 & 49.05 & 41.97 \\
No. of docs in nat. journals & 64,634 & 34,981 & 436 \\
\% of docs in nat. journals /total docs & 26.17 & 9.37 & 15.47 \\
No. of docs in nat. journals in Q1 & 138 & 577 & 1 \\
\hline
\end{tabular}

Source: survey data.

The difference in publication profile between the countries persists when analyzing the vehicles used for publication. Whereas $26.17 \%$ of the 246,939 Brazilian documents were published in national journals, for Spain, only $9.37 \%$ of the documents were published in Spanish journals. This result confirm the important role that national journals are playing in Brazil, already reported in other studies (Leta, 2012; Vargas et al. 2014). In terms of scientific production done in bilateral collaboration, $15.47 \%$ of such documents are published in Brazilian or Spanish journals.

The concentration of Brazilian scientific production in national journals is also shown by the fact that among the 30 most used journals for publication, 23 are Brazilian. These results demonstrate that Brazilian publications continue to be strongly tied to local journals, which may be now visible due to the increased number of Brazilian titles in Web of Science, which went from 22 titles in 2006 to 125 in 2012. Comparatively, Spain had 32 titles in 2006 and 99 in 2012. However, although Brazil has been gaining ground in international databases, publishing in Portuguese does not impact international visibility (Leta, 2012).

The chi-square tests performed showed that the number of documents produced in bilateral collaboration between Brazil and Spain is less than expected in Q1 journals (1,183 documents found whereas 1,588 where expected). In documents published in multilateral collaboration, that is, Brazil, Spain and other countries, the results are higher than expected $(2,262$ documents found whereas 1,857 where expected). The chi-square tests has $\mathrm{P}=<0.005$ degree of association and contingency coefficient $=0.26$.

In relation to citations, Table 3 shows that Spanish scientific production appears to be more cited than Brazilian, especially during the first two years of the period analyzed. In more recent documents, the number of citations per document is similar. Bilateral collaboration undoubtedly has a lesser impact in each one of the countries. In turn, multilateral collaboration is notably larger.

Table 3: Distribution of citations to documents from Brazil, Spain and in collaboration indexed on Web of Science databases, 2006-2012.

\begin{tabular}{|c|c|c|c|c|c|c|c|c|c|c|c|c|}
\hline \multirow[b]{2}{*}{ Year } & \multicolumn{3}{|c|}{ Brazil } & \multicolumn{3}{|c|}{ Spain } & \multicolumn{3}{|c|}{ Bilateral collaboration } & \multicolumn{3}{|c|}{ Multilateral collaboration } \\
\hline & $\begin{array}{l}\text { No. } \\
\text { docs }\end{array}$ & Citations & \begin{tabular}{|l} 
Cit. \\
/doc \\
\end{tabular} & No. docs & Citations & $\begin{array}{l}\text { Cit. } \\
\text { /doc }\end{array}$ & $\begin{array}{l}\text { No. } \\
\text { docs }\end{array}$ & Citations & $\begin{array}{l}\text { Cit. } \\
\text { /doc }\end{array}$ & No. docs & Citations & \begin{tabular}{|l} 
Cit. \\
$/$ doc \\
\end{tabular} \\
\hline 2006 & 22,922 & 237,527 & 10.36 & 41,702 & 524,710 & 12.58 & 230 & 2,112 & 9.18 & 481 & 12,659 & 26.32 \\
\hline 2007 & 28,858 & 236,064 & 8.18 & 46,301 & 482,281 & 10.42 & 292 & 2,111 & 7.23 & 536 & 14,616 & 27.27 \\
\hline 2008 & 34,449 & 229,376 & 6.66 & 50,462 & 412,782 & 8.18 & 400 & 2,595 & 6.49 & 707 & 16,420 & 23.22 \\
\hline 2009 & 36,684 & 189,415 & 5.16 & 54,392 & 313,203 & 5.76 & 416 & 1,921 & 4.62 & 800 & 11,361 & 14.20 \\
\hline 2010 & 39,193 & 134,813 & 3.44 & 56,035 & 186,213 & 3.32 & 429 & 995 & 2.32 & 934 & 8,514 & 9.12 \\
\hline 2011 & 41,504 & 78,086 & 1.88 & 59,441 & 61,828 & 1.04 & 506 & 360 & 0.71 & 1,176 & 4,362 & 3.71 \\
\hline 2012 & 43,329 & 29,256 & 0.68 & 64,980 & 72,937 & 1.12 & 546 & 381 & 0.70 & 1,483 & 7,268 & 4.90 \\
\hline
\end{tabular}


Research results from Royal Society (2011) regarding most cited partners showed that Brazil and Spain scientific collaboration do not result into three-fold increase in citations. Brazil achieved a three-fold increase at its domestic publication by collaboration with Australia, Canada, Japan and Netherlands. Spain achieved this increase by collaborating with Australia and Japan. Table 3 confirm the Royal Society results regarding impact, however, the growing of percentiles at Q1 journal is an important advantage to Brazil.

At the level of WoS categories, it was found a noteworthy partnership between Brazil and Spain in Engineering, Chemical; Food science \& technology; Soil Science; Chemistry Dietetic Applied; Nutrition; Agriculture, Multidisciplinary; Toxicology; and Physiology. In these areas, bilateral co-authorship exceeds by $80 \%$ the co-authorship with other countries. In other areas where a high level of collaboration between both countries is observed, such as Physics, co-authorship occurs along with other countries.

To analyse the impact of collaboration by areas the WoS categories were aggregate in 12 major areas proposed by Glanzel and Schubert (2003). Using this analysis it is possible to know if scientific collaboration improves the publication quality, measured by JCR Quartil. The results are presented in Table 4.

Table 4: Documents from Brazil, Spain and in bilateral collaboration indexed on Web of Science databases according to Q1 journals and categories, 2006-2012.

\begin{tabular}{|c|c|c|c|c|c|c|}
\hline \multirow[b]{2}{*}{$\begin{array}{l}\text { Categories Glänzel \& } \\
\text { Schubert (2003) }\end{array}$} & \multicolumn{2}{|c|}{ BRAZIL } & \multicolumn{2}{|c|}{ SPAIN } & \multicolumn{2}{|c|}{ BR-SP } \\
\hline & $\begin{array}{l}\% Q 1 \\
\text { withou } \\
\text { t coll. }\end{array}$ & $\begin{array}{l}\text { \%Q1 } \\
\text { coll. } \\
\text { other } \\
\text { countries }\end{array}$ & $\begin{array}{l}\% \mathrm{Q} 1 \\
\text { witho } \\
\text { ut coll. }\end{array}$ & $\begin{array}{l}\text { \%Q1 } \\
\text { coll. } \\
\text { other } \\
\text { countries }\end{array}$ & $\begin{array}{l}\text { \%Q1 } \\
\text { BILATERAL } \\
\text { Coll. }\end{array}$ & $\begin{array}{l}\text { \%Q1 } \\
\text { MULTILATERAL } \\
\text { Coll. }\end{array}$ \\
\hline $\begin{array}{l}\text { Agriculture \& } \\
\text { Environment }\end{array}$ & 19,20 & 52,74 & 62,31 & 63,56 & 51,86 & 56,52 \\
\hline $\begin{array}{l}\text { Biology (Organismic } \\
\text { \& Supraorganismic } \\
\text { Level) }\end{array}$ & 19,51 & 39,65 & 47,16 & 54,18 & 37,12 & 47,42 \\
\hline Biomedical Research & 32,25 & 47,43 & 45,86 & 56,61 & 44,40 & 49,72 \\
\hline $\begin{array}{l}\text { Biosciences } \\
\text { (General, } \\
\text { Cellular\&Subcellular } \\
\text { Biology; Genetics) }\end{array}$ & 26,61 & 44,96 & 50,93 & 60,00 & 32,44 & 43,13 \\
\hline Chemistry & 33,92 & 48,57 & 64,75 & 63,01 & 53,04 & 51,79 \\
\hline $\begin{array}{l}\text { Clinical And } \\
\text { Experimental } \\
\text { Medicine I (General } \\
\text { \& Internal Medicine) }\end{array}$ & 35,75 & 58,95 & 42,99 & 69,53 & 41,73 & 66,61 \\
\hline $\begin{array}{l}\text { Clinical And } \\
\text { Experimental } \\
\text { Medicine II (Non- } \\
\text { Internal Medicine } \\
\text { Specialties) }\end{array}$ & 27,63 & 51,77 & 41,93 & 63,35 & 38,14 & 59,14 \\
\hline Engineering & 42,89 & 46,98 & 46,59 & 49,75 & 61,90 & 56,72 \\
\hline $\begin{array}{l}\text { Geociences \& Space } \\
\text { Sciences }\end{array}$ & 36,76 & 63,56 & 47,87 & 71,48 & 54,90 & 78,66 \\
\hline Mathematics & 33,07 & 38,69 & 37,65 & 41,01 & 42,25 & 41,57 \\
\hline $\begin{array}{l}\text { Neuroscience \& } \\
\text { Behavior }\end{array}$ & 30,68 & 49,92 & 43,9 & 56,15 & 40,82 & 48,45 \\
\hline Physics & 43,39 & 60,39 & 59,6 & 67,60 & 54,76 & 73,92 \\
\hline
\end{tabular}

Source: survey data. 
Table 4 shows that for Brazil the output without scientific collaboration presents lower Q1 percentiles when comparing to output in international collaboration. There is a great difference in areas as Agriculture \& Environment (19.20\% versus 52.74\%) and Clinical and Experimental Medicine II (27.63\% versus $51.77 \%$ ). For Spain, publication without collaboration presents a bit lower percentiles at Q1 journals when comparing to publication in international collaboration, but it is not so important difference between then as in Brazilian case.

It is interesting to see that when the two countries work in bilateral collaboration all the Q1 percentiles grow for Brazil, while for Spain there is a variety of solutions. For some areas both countries improve publication quality, such as Engineering and Geosciences, areas in which collaboration between Brazil and Spain can be consider prominent. The analyses of multilateral collaboration show the growth of all Q1 percentiles when comparing with Brazilian output without collaboration in almost all areas. For Spain, multilateral collaboration improves Q1 especially at Geoscience and Physics.

\section{CONCLUSIONS}

The amount of scientific output between Brazil and Spain is not significant for either of the two countries. However, the rate of growth of production done in collaboration is greater than the rate of individual growth in both countries. The increased number of agreements and the incentives given to projects in collaboration between the countries could expand this partnership.

For Brazil, international scientific collaboration raises the number of articles published in Q1 journals. Therefore, the country should continue promoting this type of collaboration. For Spain, collaboration with Brazil is not reflected in impact. However, collaboration of each of the countries with others considerably boosts publishing in Q1 journals and the number of citations received. Thus, multilateral collaboration is beneficial to both countries in terms of citations and publication in Q1 journals. The subject analysis reveals that for Brazil, collaboration with Spain is an advantage in all areas, even when is a bilateral collaboration or when both countries are part of a network. For Spain, nevertheless, scientific collaboration with Brazil is not impressive. Both countries grow in quality when publish together in Engineering and are able to publish in better journals when work at multilateral collaboration. Evidently there are strengths in both countries that enhance collaboration in these fields.

It was also noted that in Brazil the focus is publication in national journals, coupled with a small percentage of documents produced in international collaboration and the small impact of this production. Change the extremely national publishing profile could be an important factor to direct to internationalization of Brazilian scientific research. It is believed that the expansion of international collaboration plays a decisive role in expanding the possibilities of publishing in acclaimed journals.

Future works should analyze the distribution of grants by Brazilian funding agencies for collaborative projects with Spain, and other European countries, according to subject areas.

\section{ACKNOWLEDGMENTS}

The authors would like to thank the financial support provided by Ministerio de Educación, Cultura y Deporte from Spain, CAPES and CNPq from Brazil. 


\section{REFERENCES}

BRIDGSTOCK, M. The quality of single and multiple authored papers; an unresolved problem. Scientometrics, v.21, n. 1, p. 37-48, 1991.

CONSELHO NACIONAL DE DESENVOLVIMENTO CIENTÍFICO E TECNOLÓGICO. Cooperação internacional. 2015. Available at: http://cnpq.br/cooperacao-internacional. Acessed: 30 jun. 2015.

COORDENAÇÃO DE APERFEIÇOAMENTO DE PESSOAL DE NÍVEL SUPERIOR. Programa CAPES-DGPU. 2015. Available at: < http://www.capes.gov.br/cooperacao-

internacional/espanha/capesdgpu > . Acessed: 30 jun. 2015.

DE FILIPPO, D.; BARRERE, R.; GÓMEZ, I. Características e impacto de la producción científica en colaboración entre Argentina y España. Revista Iberoamericana de Ciencia, Tecnología y Sociedad, v.6 n.16, p.179-200, 2010.

DE FILIPPO, D. et al. Perfil de Colaboración Científica del Sistema Español de Educación Superior: Análisis de las Publicaciones en Web of Science (2002-2011). Revista Española de Documentación Científica, v.37, n.4, p.1-18, 2014.

FRAME, J. D.; CARPENTER, M. P. International research collaboration. Social Studies of Sciences, n. 9, p. 481-497, 1979.

FUNDAÇÃO DE AMPARO À PESQUISA DO ESTADO DE SÃO PAULO. Indicadores de ciência e tecnologia e inovação em São Paulo 2010. São Paulo: FAPESP, 2011.

FUNDAÇÃO DE AMPARO À PESQUISA DO ESTADO DE SÃO PAULO. Convênios e acordos de cooperação. 2015. Available at: http://www.fapesp.br/acordos/. Acessed: 01 jul. 2015.

GLANZEL, W.; SCHUBERT, A. A new classification scheme of science fields and subfields designed for scientometric evaluation purpose. Scientometrics,

v. 56, n. 3, p. 357-367, 2003.

GÓMEZ, I. et al. Analysis of the structure of international scientific cooperation networks through bibliometric indicators. Scientometrics, v. 44, n. 3, p. 441-457, 1999.

KIM, E. et al. The Effects of Leadership Characteristics on the Performance of R\&D Projects. In: PICMET 2006 Proceedings, 9-13 Julio, Estambul.

LETA, J. Brazilian growth in the mainstream science: the role of human resources and national journals. Journal of Scientometric Research, v. 1, n. 1, p. 44-52, 2012.

LETA, J. et al. A macro-level study of science in Brazil: seven years later. Encontros Bibli, v. 18, n. 36, p. 51-66, 2013.

LEWISON, G. The advantages of dual nationality. New Scientist, n. 130, p. 50-51, 1991.

LUUKKONEN, T. et al. Understanding patterns of international scientific collaboration.

Science, Technology \& Human Values, v. 17, p. 101-126, 1992.

MOURA, A. M. M. et al. Panorama da produção conjunta entre Brasil e Espanha indexada na WoS entre 2006-2012: indicadores de atividade, especialização e colaboração. Informação \& Sociedade, v. 25, n. 1, p. 67-82, 2015.

NARIN, F.; WHITLOW, E.S. Scientific cooperation in Europe and the citation of multinational co-authored papers. Scientometrics, v. 21, n. 3, p. 313-323, 1991. 
ROYAL SOCIETY. Knowledge, networks and nations: global scientific collaboration in the $21^{\text {st }}$ century. London: Elsevier. Available at: http://royalsociety.org/policy/reports/knowledge-networks-nations. Acessed: 10 mar. 2016.

VAN RAAN, A. The influence of international collaboration on the impact of research results: some simple mathematical considerations concerning the role of self-citations. Scientometrics, v. 42, n. 3, p. 423-428, 1998.

VANZ, S.A.S.; STUMPF, I.R.C. Scientific output indicators and scientific collaboration network mapping in Brazil. Collnet Journal of Scientometrics and Information Management, v. 6, n. 2, p. 1-20, 2012.

VARGAS, R. A. et al. The role of national journals on the rise in Brazilian Agricultural Science publications in Web of Science. Journal of Scientometric Research, v. 3, n. 1, p. 28-36, 2014.

WAGNER, C.; LEYDESDORFF, L. Six case studies of international collaboration in Science. Scientometrics, v. 62, n. 1, p. 3-26, 2005.

ZITT, M. et al. Shadows of the past in international cooperation: collaboration profiles of the top five producers of science. Scientometrics, v. 47, n. 3, p.627-657, 2000.

Editores do artigo: Adilson Luiz Pinto, Rafaela Paula Schmitz e Enrique Muriel-Torrado 